DOI: 10.34015/2523-4552.2020.1.22

УДК 343.8

Колб Р. O.,

магістр права та банківської справи, консультант АТ КБ «Приватбанк»

ORCID: 0000-0003-0187-3391

\title{
ПРО ДЕЯКІ ПРАКТИЧНІ АСПЕКТИ КРИМІНОЛОГІЧНОЇ ХАРАКТЕРИСТИКИ ЗЛОЧИНІВ, ВЧИНЕНИХ У СФЕРІ ВИКОНАННЯ ПОКАРАНЬ УКРАЇНИ
}

У статті з'ясовано сутність і зміст кримінологічної характеристики злочинів, які мають місце в органах та установах виконання покарань, а також доведено їх практичну значущість для сфери виконання покарань та запобігання рецидивної злочинності в цілому в Україні.

Ключові слова: кримінологічна характеристика; злочин; засуджений; персонал колоній; місця позбавлення волі; запобігання; рецидивна злочинність;.

В статье установлены сущность и содержание криминологической характеристики преступлений, имеющих место в органах и учреждениях по исполнению наказаний, а также доказано ее практическое значение для сферы исполнения наказаний и профилактики рецидивной преступности в целом в Украине.

Ключевые слова: криминологическая характеристика; преступление; осужденный; персонал колоний; места лишения свободы; профилактика; рецидивная преступность.

Постановка проблеми. Як свідчить практика, для організації ефективної діяльності по запобіганню вчиненню тих чи інших злочинів інколи бракує відомостей, що стосуються їх змісту та сутності. В кримінології таке узагальнення даних про конкретний злочин називають кримінологічною характеристикою [1, c. 92].

Особливо актуальною зазначена проблема $є$ для сфери виконання покарань, одним із ключових завдань якої $\epsilon$ запобігання рецидивної злочинності в Україні. Більш того, як у нормах матеріального права (зокрема, в ч. 2 ст. 50 Кримінального кодексу (далі - КК) України), так і в нормах кримінально-виконавчого $\begin{array}{lll}\text { права (ч. } 1 & \text { ст. } 1 \text { Кримінально- }\end{array}$ виконавчого кодексу КВК)) до системних елементів мети покарання віднесено діяльність по запобіганню вчиненню нових злочинів як засудженими, так і іншими особами.

Проте, через низьку ефективність даного виду запобіжної діяльності, включаючи й недостатність інформації щодо особи злочинця та в цілому - про середовище, причини та умови, що детермінували вчинення того чи іншого злочину, тощо - щорічно кількість злочинів, які вчиняються в органах та установах виконання покарань (УВП) України у розрахунку на 1 тис. засуджених $є$ не- 
змінною (навіть при зменшенні у декілька разів загальної кількості цих осіб [2]). Так, у 1991 році засудженими, які відбували покарання у виді позбавлення волі, було вчинено 800 злочинів на 153 тис. осіб, що тримались в установах виконання покарань (УВП) (у розрахунку на 1 тис. засуджених це складало 3,9 злочини (у 1990 р. 4,44)) [3, с. 1].

У свою чергу, персонал колоній у 1991 році вчинив 19 злочинів [3, c. 22].

У 1999 році (першому році самостійного функціонування органів та УВП в системі органів державної виконавчої влади в Україні [4]) з боку засуджених, які тримались в УВП, було зареєстровано 429 злочинів (рівень злочинності склав 3,85 злочини) [5, с. 11] при збільшенні загальної кількості цих осіб за 10-річний період майже на 10 тис. (до 164 тис. засуджених) [5, с. 62], а з участю персоналу УВП - 6 злочинів [5, с. 62].

У 2010 році (останньому періоді самостійної діяльності органів та установ виконання покарань [6]) засудженими, які відбували покарання в УВП, було вчинено 404 злочини (рівень злочинності у розрахунку на 1 тис. осіб склав 3, 52 (у 2009 р. - 3,85) [7, с. 3], при зменшенні кількості засуджених на 34 тис. (до 130 тис. 380 засуджених)) [7, с. 56], а з участю персоналу УВП - 93 особи [8, c. 322-345].

У 2016 році (часу активних реформ у сфері виконання покарань та повного підпорядкування органів та установ виконання покарань Міністерству юстиції України [9]) засудженими, які тримались в УВП, було вчинено 298 злочинів (коефіцієнт злочинності склав 4, 91 у розрахунку на 1 тис. осіб (у 2015 - 6,54) при зме- ншенні загальної кількості засуджених більш, ніж на 13 \% у порівнянні 3 2015 роком [10, с. 1-12]. У той самий час, у 2016 році персоналом УВП було вчинено 102 злочини (у 2015 р. 111) [10, с. 12].

Постановка завдання. Отже, якщо узагальнити показники злочинності у сфері виконання покарань на протязі 26-річного періоду (19912016 рр.), то слід констатувати, що, не дивлячись на суттєве зменшення кількості засуджених, які відбували покарання у кримінально-виконавчих установах відкритого (виправні центри) та закритого типу (виховні та виправні колонії) (ч. ч. 2, 3 ст. 11 КВК України), із 152 тис. осіб у 1991 році до 61 тис. засуджених у 2016 році, рівень злочинності цих осіб у розрахунку на 1 тис. 3 3,9 злочинів у 1991 році збільшився до 4,91 у 2016 році.

Аналогічні негативні тенденції склались і з персоналом УВП, кількість вчинених злочинів яких з 19 у 1991 році зросло до 102 у 2016 році (ріст у 5,4 рази абр на $81,4 \%$ ).

Таким чином, в наявності складна прикладна проблема, яка в умовах проведення в Україні заходів, визначених у Концепції реформування (розвитку) пенітенціарної системи України, що схвалена у вересні 2017 року розпорядженням Кабінету Міністрів України [11], потребує вирішення, включаючи й на доктринальному рівні.

Саме зазначені обставини й обумовили вибір теми даної наукової статті, а також визначили їі головне завдання - довести необхідність більш активного та ефективного використання у запобіганні злочинам у сфері виконання покарань України можливостей кримінологіч- 
ної характеристики - як одного із дійових засобів інформаційного забезпечення даного виду соціальнопрофілактичної діяльності.

Аналіз останніх досліджень і публікацій. Як показали результати вивчення наукової літератури, постійним предметом наукових досліджень кримінологічна характеристика $\epsilon$ в працях О.М.Бандурки,

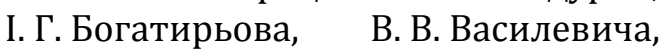
В. В. Голіни, Б. М. Головіна, О. М. Джужи, Т.А. Денисової, О. Г. Колба, А. В. Савченка, В. О. Тулякова, В. І. Шакуна та інших сучасних вчених.

Поряд з цим, дані комплексного вивчення сфери виконання покарань через призму відомостей, що характеризують злочинність двох інтегрально протилежних систем (засуджених і персоналу УВП) у наукових джерелах не здійснено, хоча необхідність у цьому $є$ очевидною, про що свідчать приведений вище аналіз статистичних даних злочинності за 1991-2016 роки.

Виклад основного матеріалу. Аналіз наукових та навчальнометодичних видань свідчить про те, що кримінологічну характеристику злочинів мова ведеться у підручниках, навчальних посібниках та інших кримінологічних джерелах, а також у дисертаціях. Поряд з цим, досі теоретичні спори та дискусії з означеної проблематики не закінчені, що, без сумніву, й позначається на ефективності практичної діяльності по запобіганню злочинам.

У повній мірі це стосується й сфери виконання покарань, у якій також відсутні єдині позиції щодо змісту та елементів кримінологічної характеристики злочинів. Так, В. В.Лопоха у своїй кандидатській дисертації вивів наступне визначен- ня поняття «кримінологічна характеристика злочинів, що вчиняються персоналом виправних колоній у ході виконання покарання у виді позбавлення волі» - це стійкі відомості про рівень, структуру, динаміку та географію злочинних діянь, а також про осіб, що їх вчиняють, та потерпілих від злочинів, тобто нові відомості про стан злочинів, що вчиняються даною категорією персоналу Державної кримінальновиконавчої служби (ДКВС) України, повні та точні знання про ці суспільно небезпечні явища для ефективного та науково обгрунтованого запобігання зазначеного виду злочинів [12, c. 68] .

У свою чергу, А. В. Головкін та Ю. О. Левченко переконані, що під кримінологічною характеристикою злочинів, які вчиняються персоналом ДКВС України, слід розуміти узагальнені за допомогою статистичних та інших наукових методів дослідження офіційні відомості про стан, рівень, структуру, динаміку та географію злочинів, що вчиняють зазначені суб'єкти, кримінологічнозначущі дані про цих осіб, а також про потерпілих від цих злочинів та про детермінанти вчинення і ціну цих суспільно небезпечних діянь, що отримані з метою розробки науково обгрунтованих заходів по запобіганню даного виду злочинів [1, с. 94].

Результати дослідження наукової літератури показали, що у ній висвітлені й інші підходи 3 означених питань. Так, А. В. Годлевська-Коновалова у своїх наукових працях сформулювала авторське визначення поняття «кримінологічної характеристики злісної непокори вимогам адміністрації установи виконання покарань», а саме - це узагальнені статис- 
тичні дані науково обгрунтовані відомості кримінально-правового змісту про рівень, структуру, динаміку, ціну, характер, географію й топографію цього злочину, а також про його детермінанти та про осіб, які їх вчиняють і потерпілих від вказаної протиправної діяльності, що мають кримінологічне значення [13, с. 8].

Знову ж таки, як свідчить практика, здійснення кримінологічної характеристики будь-яких злочинів, $\epsilon$ необхідною умовою, не тільки всіх видів запобіжної діяльності, а й кримінологічного прогнозування та планування протидії злочинності у цілому в державі, враховуючи, що і перше $[14$, с. 171$]$, і друге $[14$, с. $174-$ 175] $\epsilon$ необхідною умовою діяльності всіх суб'єктів запобігання злочинам.

Отже, якщо узагальнити зазначені та інші підходи, що сформувались серед науковців щодо змісту кримінологічної характеристики злочинів [15, с. 11-12], то можна зробити висновок, що їі слід віднести до одного із елементів інформаційного забезпечення діяльності щодо запобігання злочинності та злочинним проявам в Україні.

Як з цього приводу слушно зауважив А. П. Закалюк, вирішення зазначених завдань стосовно діяльності по запобіганню злочинам обумовлюються, у тому числі інформаційним забезпеченням щодо їх реалізації, передусім щодо опосередкованого та безпосереднього предмета діяльності, тобто стосовно злочинності, iї причин і умов, інших детермінантів, динаміки їхньої зміни, спрямування i змісту запобіжних заходів і засобів, оцінки їхньої результативності, відповідних знань та умінь (навичок) суб'єктів діяльності $[16$, с. 359$]$. Поряд 3 цим, як у свій час встановив А. П. Закалюк, інформаційне забезпечення запобіжної діяльності в Україні знаходиться на низькому рівні [16, с. 363].

Показовою у цьому є ситуація, що склалась на нормативноправовому та практичному рівнях у сфері виконання покарань. Зокрема, мова ведеться про те, що потрібна для забезпечення запобіжної діяльності в УВП інформація, передусім про причини, умови, інші детермінанти злочинності, окремих її видів, на сьогодні відсутня, через що вона не піддається аналізу та не враховується при розробці і здійсненні заходів щодо удосконалення організації запобігання злочинам i правопорушенням, як з боку засуджених, так i персоналу органів та установ виконання покарань.

Так, у ст. 104 КВК України одним із завдань оперативнорозшукової діяльності (ОРД) в колоніях визначено вивчення причин i умов, що сприяють вчинення злочинів та інших правопорушень, але будь-яких правових механізмів його реалізації законодавець не створив. Відсутні вони й на відомчому інформаційно-правовому рівні, позаяк жоден із цих актів не зобов'язує персонал УВП займатись цією діяльністю.

Більш того, окремі норми КВК 3 цих питань $є$ суперечливими та не забезпечують мети запобігання злочинності у сфері виконання покарань. Зокрема, як це зазначено в ч. 2 ст. 35 КВК, за результатами у тому числі кримінологічної характеристики на кожного засудженого складається індивідуальна програма соціально-виховної роботи, яка затверджується начальником колонії.

У той самий час, у ч. 1 ст. 95 даного Кодексу визначено, що для цьо- 
го персоналу УВП надається тільки 14 діб, що свідчить про формальне відношення законодавства до створення відповідних правових гарантій, спрямованих на виявлення причин i умов, що сприяли вчиненню злочинів особами, за які вони засуджені чи тримаються у місцях позбавлення волі. Як наслідок: щорічно у структурі осіб, які вчинили повторні злочини у ході відбування даного покарання, засуджені, які перебували на профілактичних обліках УВП, складають 34 \%, а порушники встановленого порядку виконання та відбування покарання у виді позбавлення волі - $66 \%$ [5, с. 13].

Саме відсутність належного інформативного забезпечення й привела ріст злочинності персоналу УВП майже $90 \%$ у сьогоденні, по зрівнянню з 1991 роком. I, це при тому, що ще у 1999 році до Кабінету Міністрів України Академією правових наук України (тепер - Національна академія правових наук України) було надано наукові розробки щодо причин і умов деяких видів злочинності з пропонуванням розроблення наукових засад створення Державної автоматизованої системи кримінологічної інформації (ДАСКУ), яка мала містити інформацію про причини й умови злочинності, тенденції їх зміни [16, с. 363-364]. Але досі зазначена інформаційна система не створена через відсутність фінансових можливостей у державі та складність в отриманні інформації від різних суб'єктів запобіжної діяльності.

Пропозиції аналітичного характеру можна зустріти й в наукових розробках фахівців у галузі криміна- льно-виконавчого права. Так, О. Г. Колб ще у 2007 році обгрунтував необхідність доповнення КВК України спеціальним розділом, у якому закріпити об'єкти кримінологічного впливу на особу; суб'єкти; принципи запобіжної діяльності тощо [17, с. 131-138], проте досі даний Кодекс 3 означених питань не зазнав жодних видозмін.

У свою чергу, у 2019 році А. В. Годлевська-Коновалова у своїй кандидатській дисертації слушно запропонувала доповнити КВК ст. 104-1 «Об'єкти запобігання злочинам» (засуджені, схильні до втечі; захоплення заручників; злісної непокори тощо.) [13, с. 14].

На даний час це питання регулюється розділом XXIII Правил внутрішнього розпорядку установ виконання покарань (ПВР УВП) [18], що суперечить вимогам ч. 2 ст. 19 , ч. 3 ст. 63 та п. 14 ст. 92 Конституції України, відповідно до яких правообмеження для засуджених та діяльності у цьому контексті органів та установ виконання покарань визначаються виключно на підставі законy.

Висновки. Таким чином, результати проведеного аналізу дають можливість стверджувати, що чітке визначення змісту кримінологічної характеристики злочинів має не тільки і не стільки теоретичне значення, скільки практичне спрямування як необхідний елемент інформаційного забезпечення злочинам у цілому в Україні (наприклад, 3 питань рецидивної злочинності) та кримінальним правопорушень у сфері виконання покарань, зокрема. 


\section{Список використаних джерел}

1. Корупційні та інші злочини, що вчиняються у сфері виконання покарань: кримінологічна характеристика та запобігання : навч. посібник / за ред. д. ю. н., проф. О. Г. Колба. Київ: Видавничий дім «Кондор», 2019. 444 с.

2. Дані про чисельність засуджених та ув'язнених, які тримаються у кримінально-виконавчих установах та слідчих ізоляторах України станом на 01.07.2019 року. URL: https://kvs.gov.ua/2019/harakteristika/01.07.2019.pdf. (дата звернення: 03.02.2020).

3. Некоторые показатели деятельности уголовно-исполнительной системы МВД Украины в 1991 году: Информ. бюллетень. Киев: ГУИН МВД Украины, 1992. 28 с.

4. Про виведення Державного департаменту України 3 питань виконання покарань 3 підпорядкування МВС України: Указ Президента України від 12 березня 1999 року. № 248/99. Офіційний вісник України. 1999. № 11. Ст. 24.

5. Оперативно-службова та виробничо-господарська діяльність органів і установ виконання покарань України у 1999 році: Інформ. бюлетень. Київ : ДДУПВП, 2000. № 4.84 c.

6. Про оптимізацію системи центральних органів виконавчої влади : Указ Президента України від 9 грудня 2010 року. Офіційний вісник України. 2010. № 94. Ст. 3334.

7. Про діяльність підрозділів охорони, нагляду і безпеки кримінально-виконавчих установ у 2010 році : Інформ. бюлетень. Київ: ДПтС України, 2011. Кн. 1. 70 с.

8. Кримінологічні та оперативно-розшукові засади запобігання злочинам i правопорушенням, що вчиняються персоналом виправних колоній : Монографія. / О. Г. Колб, О. М. Джужа, В. В. Василевич та ін.; за заг. ред. д. ю. н., проф., членкореспондента НАПНрУ В. В. Коваленка. Київ: Атіка, 2011. 367 с.

9. Про ліквідацію територіальних органів управління Державної пенітенціарної служби та утворення територіальних органів управління Міністерства юстиції : постанова Кабінету Міністрів України від 18 травня 2016 року № 348. Офіційний вісник України. 2016. № 44. Ст. 111.

10. Про стан правопорядку, ізоляції та нагляду, діяльність підрозділів охорони, пожежної безпеки та воєнізованих формувань Державної кримінально-виконавчої служби України у 2016 році : інформ. бюлетень. Київ: Департамент ДКВС Міністерства юстиції України, 2017. 34 с.

11. Концепція про реформування (розвиток) пенітенціарної системи України, схвалена розпорядженням Кабінету Міністрів України від 13 вересня 2017 року. Урядовий кур'єр. 22.09.2017 р. № 178.

12. Лопоха В. В. Запобігання злочинам, що вчиняються персоналом виправних колоній України : дис... канд. юрид. наук : 12.00.08. Київ: Інститут адвокатури України, 2016. 224 с.

13. Годлевська-Коновалова А. В. Запобігання злісній непокорі вимогам адміністрації установи виконання покарань : автореф... дис. канд. юрид. наук : 12.00.08. Київ: Класичний приватний університет, 2019. 20 с.

14. Кримінологія : підручник для студентів вищ. навч. закл. / за заг. ред. О. М. Джужи. Київ: Юрінком Інтер, 2002. 416 с.

15. Шкуро В. В. Кримінологічна характеристика та протидія суїцидальності як фоновому для злочинності явищу : дис... канд. юрид. наук : 12.00.08. Харків: ХНУВС, 2016. 250 c.

16. Закалюк А. П. Курс сучасної української кримінології: теорія і практика : У 3 кн. Київ: Видавничий Дім «Ін Юре», 2007. Кн. 1: Теоретичні засади та історія української кримінологічної науки. 424 с. 
17. Колб О. Г. Установа виконання покарань як суб'єкт запобігання злочинам : дис... докт. юрид. наук : 12.00.08. Київ: НАВС України, 2007. 513 с.

18. Правила внутрішнього розпорядку установ виконання покарань : затв. наказом Міністерства юстиції України від 28 серпня 2018 року № 2823/5. Обіційний вісник України, 2018. №70. 285 с.

\section{References}

Kolb, O. (red.). (2019). Koruptsiini ta inshi zlochyny, shcho vchyniaiutsia u sferi vykonannia pokaran: kryminolohichna kharakterystyka ta zapobihannia. Kyiv: Vydavnychyi dim «Kondor» [in Ukrainian].

Kolb, O., Dzhuzha, O., Vasylevych, V. (2011). Kryminolohichni ta operatyvno-rozshukovi zasady zapobihannia zlochynam $i$ pravoporushenniam, shcho vchyniaiutsia personalom vypravnykh kolonii. Kyiv: Atika, [in Ukrainian].

Lopokha, V. V. (2016). Zapobihannia zlochynam, shcho vchyniaiutsia personalom vypravnykh kolonii Ukrainy (dys... kand. yuryd. nauk). Kyiv: Instytut advokatury Ukrainy [in Ukrainian].

Hodlevska-Konovalova, A. V. (2019). Zapobihannia zlisnii nepokori vymoham administratsii ustanovy vykonannia pokaran. (Avtoref ... dys. kand yuryd nauk). Kyiv: Klasychnyi pryvatnyi universytet [in Ukrainian].

Dzhuzha, O. M. (red.). (2002). Kryminolohiia. Kyiv: Yurinkom Inter [in Ukrainian].

Shkuro, V. V. (2016). Kryminolohichna kharakterystyka ta protydiia suitsydalnosti yak fonovomu dlia zlochynnosti yavyshchu. (Dys... kand. yuryd. nauk). Kharkiv: KhNUVS [in Ukrainian].

Zakaliuk, A. P. (2007). Kurs suchasnoi ukrainskoi kryminolohii: teoriia i praktyka. Kyiv: Vydavnychyi Dim «In Yure» [in Ukrainian].

Kolb, O. H. (2007). Ustanova vykonannia pokaran yak sub'iekt zapobihannia zlochynam (dys... dokt. yuryd. nauk). Kyiv: NAVS [in Ukrainian].

\section{R. Kolb, Master of Laws and Banking Consultant of JSC CB "Privatbank" ORCID: 0000-0003-0187-3391}

\section{On some practical aspects of criminological characteristics of crimes committed in the sphere of execution of punishments of Ukraine}

As practice has shown, in order to organize effective activities to prevent the commission of certain crimes, sometimes there is a lack of information regarding their content and nature. In criminology, such a generalization of data on a specific crime is called a criminological characteristic.

Particularly urgent is the problem identified in the field of punishment, one of the key tasks of which is the prevention of recidivism in Ukraine. Moreover, both in the rules of substantive law (in particular, in Part 2 of Article 50 of the Criminal Code (hereinafter referred to as the Criminal Code) of Ukraine), and in the rules of criminal law (Part 1 of Article 1 of the Penal Code of the KVC) systematic elements of the purpose of punishment include activities to prevent the commission of new crimes by both convicted persons and others.

However, due to the low effectiveness of this type of preventive activity, including the lack of information about the perpetrator and, in general, the 
environment, the causes and conditions that determined the commission of a crime, etc. - the number of crimes perpetrated in the penitentiary agencies and institutions annually (GDP) of Ukraine per 1,000 prisoners is unchanged (even if the total number of these persons is reduced by several times). For example, in 1991, convicts serving a sentence of imprisonment were charged with 800 crimes per 153 thousand persons held in prisons (the rate per 1,000 prisoners was 3.9 crimes (in $1990,4.44)$.

In 1991, the colony staff committed 19 crimes. In 1999 (the first year of selffunctioning of bodies and PECs within the system of state executive bodies in Ukraine), 429 crimes were registered by convicts who were being held in PUPs (crime rate was 3.85 crimes), while the total number of these persons increased by 10 -year period is almost 10 thousand (up to 164 thousand convicts), and with the participation of police personnel - 6 crimes.

In 2010 (the last period of independent activity of bodies and institutions of punishment execution), 404 crimes were committed by convicts who served their sentences in the prison (the crime rate per 1,000 persons was 3, 52 (in 2009 3.85 ), while reducing the number of convicts by 34 thousand (up to 130 thousand 380 convicts)), and with the participation of the staff of the prison - 93 persons.

In 2016 (the time of active reforms in the sphere of punishment and full subordination of bodies and institutions of execution of sentences to the Ministry of Justice of Ukraine), 298 crimes were committed by convicts, who had a crime rate of 4.91 per 1 thousand persons (in 2015 - 6.54), while reducing the total number of convicts by more than $13 \%$ compared to 2015 . At the same time, 102 crimes were committed by police personnel in 2016 (111 in 2015).

Thus, if we summarize the crime rates in the sphere of execution of sentences during the 26-year period (1991-2016), it should be noted that, despite the significant decrease in the number of convicts who have served sentences in the penal institutions (correctional centers) and gated (correctional and correctional colonies) (part 2, 3, article 11 of the KVC of Ukraine), from 152 thousand persons in 1991 to 61 thousand sentenced in 2016, the crime rate of these persons in the calculation per 1 thousand from 3.9 crimes in 1991 increased to 4.91 in 2016.

Similar negative trends were also observed with the staff of the GDP, the number of crimes committed from 19 in 1991 to 102 in 2016 (an increase of 5.4 times by $81.4 \%$ ).

Thus, there is a complex applied problem that in the conditions of holding in Ukraine the measures defined in the Concept of reforming (development) of the penitentiary system of Ukraine, approved in September 2017 by the decree of the Cabinet of Ministers of Ukraine, needs to be solved, including at the doctrinal level.

These circumstances led to the choice of the topic of this scientific article, and defined its main task - to prove the need for more active and effective use in the field of punishment of Ukraine opportunities criminological characteristics - as one of the effective means of information support of this type of social and preventive activity.

Keywords: criminological characteristics; the crime; convicted; colony personnel; places of detention; prophylaxis; recidivism. 